Secondary publication on the edoc server of the Humboldt-Universität zu Berlin

\title{
https://doi.org/10.18452/21585
}

This is an Accepted Manuscript of an article published by Taylor \& Francis in Journal of Urban Technology in 2000, available online: http://www.tandfonline.com/10.1080/713684106

Originally published as:

Timothy Moss (2000) Unearthing Water Flows, Uncovering Social Relations: Introducing New Waste Water Technologies in Berlin, Journal of Urban Technology, 7:1, 63-84, DOI: $10.1080 / 713684106$

\section{Unearthing water flows, uncovering social relations: introducing new waste water technologies in Berlin}

\author{
Timothy Moss \\ Institute for Regional Development and Structural Planning (IRS) \\ Erkner, Germany
}

"In the past [waste] water simply flowed over the street, ... then engineers brought the water underground. The urban planners were thus free to do what they liked above ground ... and were glad that the sewers were below. And now we [water managers] are coming and laying claims to open spaces and streets. That annoys the urban planners ... . Ultimately the challenge is to make water visible."

(Excerpt from an interview with a representative of the Berlin water utility, October 1997)

\section{Introduction}

Removing waste water from urban settlements by means of underground channels was a major achievement of city planning in the nineteenth century and has since become regarded as an essential precondition for urbanization. Over the last century complex technical networks of drainage pipes, sewers, retention basins, filter beds and treatment plants have been built up in advanced societies to meet the physical expansion of cities and rising standards of hygiene and environmental protection. These technical structures are managed by a web of social structures and relations which have evolved between water engineers, urban planners and environmental regulators in response to changing demands and contextual circumstances. Out of the interaction between these technical and social systems has arisen 
over time a predominant logic - or rationale - for managing urban infrastructure which can be observed in most industrialized countries. This supply-oriented logic can be characterized as one of "expand and up-grade"; that is, a basic strategy of extending the physical networks and modernizing technical plant to meet an anticipated growth in water use and higher performance standards.

Today, this established logic of infrastructure management is being challenged by a number of emerging forces for change, as Marvin and Guy have argued convincingly for the water and energy sectors (13) (20). One of the forces for change is the growing need for, and the introduction of, new technologies which do not fit readily into either the existing technical networks or the established system of social organization underpinning the physical infrastructure. This paper is about one such technology - localized storm-water percolation and how its recent introduction on a large scale in new urban developments in Berlin is not only "unearthing" water flows, by bringing rainwater collection and treatment above ground, but also "uncovering" the complex social relations involved in rainwater management. The technology is interesting from a technical point of view because it requires the partial reordering of a centrally-structured sewer system to accommodate a localized sub-system. Beyond this, though, the technology is re-ordering the social organization of rainwater management by engaging a wider range of actors and altering the roles and responsibilities of each.

The application of this new technology raises important questions about how the social and technical components of a technological system interact to create conditions for change. This paper explores, on the one hand, how a specific technology shapes social relations; in particular, how new techniques can change the relationship between users, providers, regulators and planners in the water sector. The emphasis here is on investigating the redistribution of responsibilities and costs necessitated by the introduction of the new technology and the process of negotiation accompanying this redistribution. On the other hand, the paper asks more generally what conditions favor technological change in the first place; in particular, what kinds of pressures create openings for a new technique such as localized storm-water percolation. Here the interest lies in understanding the societal forces shaping the historical development - or trajectory - of technological systems. This is proving particularly important to water managers and urban planners today when the context of water management in industrialized countries is shifting dramatically under the impact of privatization, standardization, institutional change and growing environmental problems. Adapting technical networks to a changing context is a particularly poignant theme in Berlin, where, post-unification, a variety of new economic, organizational, commercial and environmental pressures are prompting water managers to re-think their strategies for network expansion and explore alternative ways of managing urban water systems.

The paper begins by introducing the concept of Large Technological Systems (LTS) as an analytical framework for understanding the drivers of technological change, which is then used to sketch the historical development of Berlin's waste water disposal system from the 1870 s to the late 1980s. The second section examines in more detail the multiple new challenges facing waste water management in Berlin following re-unification in 1990, the responses of key actor groups to these challenges and their consequences for technological innovation. Against this historical and contextual background the third section takes the case of localized storm-water percolation to explore the impact of one selected technology on the social organization of waste water management in the city. Finally, conclusions are drawn on the interaction between technical and social components of infrastructure systems with implications for the adaptability of Large Technological Systems. 


\section{The historical development of the waste water disposal system in Berlin: an LTS perspective}

\section{Conceptual framework of analysis: waste water networks as Large Technological Systems}

The concept of Large Technological Systems (LTS) presents a model of how technological systems develop and change in response to shifting socio-technical forces and is thus a very suitable tool for our initial analysis. The LTS concept is based on the premise that large technological systems, such as electricity or telecommunications networks, cannot be understood solely in terms of their technological components but as complex systems which link material technologies with organizations, institutional rules and cultural values (30) (16). The development of Large Technological Systems, as Thomas Hughes demonstrated in his pioneering study of the historical development of electricity networks in the USA, Britain and Germany, is determined not by technological advancement alone but by the interplay between these components (17).

Water supply and sewage disposal networks have received little attention within the LTS debate but they bear most, if not all, of the principal characteristics of Large Technological Systems. Like electricity networks they are complex systems consisting of physical artifacts (pipes, processing plant), organizations (utility companies, planning bodies) and regulatory structures (legislative framework, financial transactions). They evolved in response to the increasing complexity and problems of control relating to drinking water and sanitation needs in the late nineteenth century in Europe. Since then, under the direction of their system-builders, they have generally followed the familiar pattern of development of LTS into large-scale, centralized and hierarchical systems built around a dominant technology (such as mains sewers) and comprising several sub-systems (such as storm-water collection). Typical of many LTS, water supply and sewage disposal networks are engaged in regulating the input and output of resources on a large scale: in this case, the natural resource water and water pollutants as well as, less visibly, energy, building materials and money. Given their importance to human well-being, high capital needs and long-run cost-curves, they have traditionally - like other LTS - been treated as natural monopolies, either publicly operated or at least publicly regulated (10).

The purpose of LTS theory is to explain how actors, technologies, markets and regulations interact to shape the initiation, evolution and expansion of Large Technological Systems (12). Central to the argument are three concepts introduced by Hughes: systembuilders, momentum and reverse salients (16). The system-builders are defined as the inventors, engineers, managers, financiers and other key actors with a vested interest in a LTS. Each actor group influences a LTS in different phases of its development: the inventors creating the initial techniques, the engineers applying the techniques to solving a problem, the managers devising a suitable organizational structure and so on. The important characteristic of system-builders is their interest in promoting and protecting their own technological system against competition from other systems (16).

As a result of these efforts by the system-builders, Large Technological Systems develop a momentum of their own. Early decisions on the type of technology chosen or the way utilities are regulated limit the options for future development, guiding LTS in a particular direction. Once established, the homogenous, standardized networks become stable forces which continue to reinforce themselves internally and sustain other systems, such as urban development, externally (12). According to LTS theory the momentum of a Large Technological System increases over time; in other words, LTS grow inflexible and resistant to radical change as they stabilize, with the system-builders seeking continuously to protect their system from outside competition.

The way in which major change does occur in and between Large Technological Systems is explained in terms of reverse salients (16). Reverse salients are retarded 
components which hinder the further development of a system. These blockages might be technical, but equally social, organizational, economic or cultural. As LTS expand, reverse salients develop. In minor cases the reverse salient can be corrected within the context of the existing system. When this is not possible the solution to the problem may introduce or strengthen competing systems. Under such circumstances a "battle of systems" is engaged - a military metaphor which captures the conflictual nature of radical change according to LTS theory.

\section{Historical development of the waste water disposal system in Berlin}

How does this model of Large Technological Systems help us understand the historical development of Berlin's waste water disposal system, in particular as a socio-technical construct? Berlin's original sewer network, upon which today's system is based, was built in the 1870s according to a design by James Hobrecht and based on Rudolf Virchow's ideas for improving standards of urban hygiene. Like all system-builders of sewer networks in the nineteenth century, their overriding concern was the public health risk posed by the presence waste water in open spaces and waterways within the city (19). The common response to this definition of the problem was to export waste water from the city to surrounding areas, using closed underground channels as a means of transportation. The various designs for sewage disposal systems all followed this logic of increasing the "circulation" of waste water out of the city (26). Concern was voiced at the time about the dangers of contaminating waterways downstream of the sewage discharge points, but this environmental position was overridden by the overwhelming concern for urban hygiene, backed by the principal system-builders of the day.

Within this general consensus of concern for public health, however, the design of the sewer system was, in Berlin as in other cities across Europe, the subject of a long-standing, heated debate between pubic health officials, medical advisors, civil engineers and municipal politicians, each forming alliances to promote their own favored option (19) (9) (23). The conventional system of discharging sewage into a waterway downstream of the city, based on Chadwick's design for London's sewers in the 1830s, was eventually rejected in Berlin in favor of Hobrecht's radial system, whereby waste water was collected in 12 sectors of the city and pumped out to irrigation beds on the outskirts of the city. This system had the advantages of purifying the waste water by means of soil percolation and reducing the dimensions of the sewers in each of the 12 sectors. Both factors benefited the environment but this was not a prime motive: urban hygiene remained the driving logic.

In the following decades Berlin's sewage disposal system developed a "momentum" in the LTS sense. It was extended to meet both the growing number of household connections to the network and the rapid pace of urbanization. In the 1890s a separate sewage and rainwater system for the suburbs was added without difficulty to Hobrecht's mixed sewer system in the inner city. The consolidation and expansion of the technical system was matched by the institutionalization of waste water disposal as a municipal service, operated by a growing body of specialist officials and engineers.

The first serious "reverse salient" was encountered in the 1920s when the growing volume and toxicity of waste water proved too much for the irrigation beds to cope with. Decades of continuous percolation of sewage had reduced their capacity to purify the waste water, thus threatening the city's drinking water supplies from nearby wells. The solution to this problem grew out of the existing network structure: sewage treatment plants were built at the end points of the sewers from 1927 onwards, supplementing and gradually replacing the irrigation beds. This adaptability of Hobrecht's original system proved a major factor behind its re-stabilization in subsequent decades.

A second major reverse salient was the political - and subsequent physical - division of Berlin in the post-war period. The sewage disposal network was, in fact, the only technical 
network in the city not to be cut off by the building of the Wall, largely for hydraulic reasons, with a contractual agreement between the two halves of the city regulating the division of costs and responsibilities. Nevertheless, there were strong political reservations in West Berlin and financial considerations in East Berlin which encouraged both parties to make their own sewage disposal systems more autarkic. Here we see a classic - if extreme - case of sociopolitical factors shaping the development of a Large Technological System. In both West and East Berlin after 1961 sewage treatment plants (STPs) were built within the city limits and sewer networks re-directed to serve the new STPs. In addition, the West Berlin authorities and sewage utility were, thanks to federal subsidies, able to invest heavily in sewage disposal technologies.

By 1990, when the Berlin wall fell, the logic of "expand and up-grade" was well established in both halves of the city's waste water management. Some $98 \%$ of the city's households were connected to the public sewers, the networks were being steadily extended to meet rising water consumption and treatment plant modernized to meet stricter environmental standards. Moreover, the social organization of waste water management had changed little over the decades, with the exception of the division into two separate utilities in the West and East of the city. A small group of engineers and infrastructure planners continued to dominate strategy and ensure the momentum of "their" systems.

\section{Reinforcing and challenging the "expand and up-grade" logic post-1990: coping with multiple reverse salients}

\section{Phase of expansion}

The re-unification of Germany - and of Berlin - in 1990 brought new pressures to bear on the city's waste water disposal system on several fronts. Water consumption - and thus sewage production - was predicted to rise sharply as the regional economy grew, placing additional demands on the existing sewer network. Some outlying areas of East Berlin were still not connected to the public sewers. The principal concern in the Berlin region, however, was the pollution of waterways emanating from the sewage disposal system. On the one hand the treated effluent from sewage treatment plants in East Berlin and outside the city fell well short of Federal German and EU environmental standards. On the other hand discharges from over 100 rainwater sewers and overflows from mixed sewage systems exacerbated bacteriological pollution and the risk of eutrophication of Berlin's waterways (18). Beyond these technical challenges organizational changes to waste water management were required, primarily the amalgamation of Berlin's two water utilities and closer cooperation between Berlin and the surrounding state of Brandenburg.

The response of the two principal groups of "system-builders", the (West-)Berlin water utility and the Senate department responsible for infrastructure planning and environmental regulation, to these multiple reverse salients was to apply the "expand and up-grade" logic with greater urgency. The nature of the emerging pressures, after all, seemed to point in the direction of extending and modernizing the existing sewage disposal network. The water utility BWB, in particular, was enthusiastic to up-grade the East Berlin network to West Berlin standards, to develop new technologies for minimizing water pollution and to market its techniques and know-how (e.g. on groundwater enrichment) in Europe.

Predictions of a water crisis in Berlin as a result of the new multiple pressures had the additional effect, however, of introducing another group of actors - the research community of hydrologists, limnologists and water engineers - as key players in the debate on the future of urban water management in the city. Many of these researchers interpreted the new pressures as a challenge to develop and introduce new waste water treatment techniques and to reconceptualize waste water treatment as part of water cycle management for the whole Berlin 
region. A number of competing concepts for water cycle management were introduced in the early-to-mid 1990s, all sharing a common interest in reducing the through-flow of the region's water and re-using water locally, but each favoring different technical solutions to the waste water problem. Some envisaged "the imitation of ecological cycles with the help of intelligent technology" ( 8 p.195), raising the standard of waste water treatment and using treated effluent to replenish groundwater stocks either locally or upstream (8) (29). Such schemes for Berlin were heralded as "pioneers on the road to the sustainable recycling of fresh water" (29 p.140). Ecologists and environmental groups were skeptical of these "artificial", technical systems of recycling water, promoting instead concepts for reducing water use and closing water cycles at the local level, such as installing water meters and reusing gray water (6) (22). Some limnologists took the eco-systematic approach to extremes by suggesting the subordination of land-use in and around the city to the goal of retaining and recycling water in the region (14) (24). Within this broader debate on water cycles various concepts for the management of rainwater were discussed, including the localized percolation of urban run-off (32).

The impact of this debate in the scientific community was to prompt both the Senate and the BWB to frame their water policies increasingly in terms of an integrated approach to the region's water cycle. This is apparent in policy documents relating to water management (2) (1) as well as in policy statements by Senate officials (25) (18) (5). In the words of a senior BWB representative, "in accordance with our guiding principle "no drinking water imports, no sewage exports' [we] favor the introduction of regional water cycle management" (27) (31).

This new conceptual framework was interpreted by both the BWB and the Senate department responsible for infrastructure planning and environmental regulation (SenSUT) as supporting, rather than undermining, plans to expand and up-grade the waste water network. Preferring the arguments of the water engineers to the limnologists, the BWB and SenSUT sought technical solutions to what they saw as technical problems (Interview 1). To manage rainwater better plans were devised to construct some 93 rainwater treatment plants across the city - with the task of retaining, purifying and percolating rainwater - and 3 overflow and retention basins in the mixed rainwater/sewage systems, both making considerable demands on space in the city (28). Plans were also made to introduce localized storm-water percolation on a large scale.

\section{Phase of uncertainty}

The implementation of these ambitious plans, however, soon ran into difficulties for a number of reasons which represent - in LTS terminology - a second wave of reverse salients after 1990. Firstly, talk of an impending water supply crisis subsided as water consumption in Berlin - contrary to expectations - fell sharply by 35\% between 1989 and 1996, owing to the decline in industrial production, the rise in water rates and the growing use of water-saving appliances (3). One of the principal arguments for water recycling technologies - to maintain the city's drinking water resources - was thereby effectively sidelined. The emphasis shifted more firmly to issues of water quality, rather than quantity (Interviews 2 and 3). Secondly, the high cost of investments in up-grading the waste water network no longer seemed feasible, at least in the short term, given the budget crisis of the city government and the already high level of water rates. To take one example: just $400 \mathrm{~m}$ of rainwater overflow sewer on Potsdamer Platz had cost 16 mill. DM, one quarter of the cost of the whole sewer system of the Potsdamer Platz development (28). Thirdly, the planned privatization of the BWB - itself a consequence of the city's huge budget deficit - has encouraged BWB to take a more cautious approach to investments in order to strengthen its economic base and develop new commercial outlets (21). Finally, public sector cutbacks by the Berlin government have also 
threatened to hit subsidies on certain technologies used by the BWB, such as for groundwater replenishment.

The combination of these new factors is creating an atmosphere of uncertainty. The traditional assumptions of rising water consumption and easy cost retrieval for investments would appear to be seriously, if not permanently, challenged. The planning of infrastructure systems such as a sewer network is no longer the straightforward task of extending and upgrading the existing network but is requiring more careful consideration of the level and targets of investment and the future adaptability of the physical structures built. In terms of LTS theory, water management in Berlin would appear to be currently undergoing a transition from a phase of growth and expansion to one of stagnation and re-orientation (11). Interestingly, the reverse salients responsible for this shift are not primarily technical or environmental, but socio-economic, commercial and political.

The impact of this latest reversal has been for the BWB to re-appraise its investment plans substantially, revising the ten-year investment plan in 1997 downwards from ca. 21 to 12.2 billion DM. Today, the application of several advanced technologies, such as the construction of rainwater treatment plant and sewage overflow basins, has been put on ice as the BWB and the Senate discuss the re-distribution of costs and a revised timetable for implementation (28).

\section{4. "The rain must stay in Berlin": the case of localized storm-water percolation}

One technology that survived the re-appraisal and continues to flourish under the altered circumstances is storm-water percolation. The following section examines the widespread introduction of various techniques of rainwater collection and percolation at the local level in Berlin, analyzing the reasons for their application and the impact they are having on the social organization of waste water management in the city.

\section{The technology}

The principle of localized percolation of urban run-off involves, simply, allowing rainwater to seep into the groundwater on or near the place it falls without having to transport it via sewers or rainwater channels to a distant treatment plant or waterway. The purpose is to reduce the flow of urban run-off - a major source of surface water pollution - and to replenish local groundwater resources. At the local level of the property, housing block or street rainwater is collected and allowed to seep into the groundwater, using the soil as a natural filter. A variety of techniques have been developed recently, from open ponds and troughs to more complex trough-trench systems, accompanied by measures to minimize soil sealing and replace sealed areas with water-permeable surfaces (see Figure 1). Local conditions, such as the space available, the quantity of run-off, the permeability of the soil and groundwater levels, determine which techniques are most suitable.

\section{Figure 1: A trough-trench system for storm-water percolation}

By retaining rainwater in this way it is possible to limit substantially pollution from sewer overflows and rainwater channels entering waterways following heavy rainfall. The costly alternative of collecting and treating storm-water in large, central retention basins is thereby avoided. This explains the growing interest in Germany since the 1980s in the idea of percolating rainwater within built-up areas. Several research and demonstration projects have been funded by the Federal Government, notably in Dortmund and Zwickau, to assess the potential for storm-water percolation in urban settlements. The results reveal that percolating 
urban run-off locally is not only technically feasible for almost all settlement structures, including existing built areas, but was a more economical alternative to conventional techniques for collecting and purifying storm-water centrally (4). The technology has since been approved by the Federal Environment Agency; it is now obligatory for new urban developments in the state of Northrhine-Westphalia and other states plan to follow suit.

\section{Application in Berlin}

The appeal of the technology of storm-water percolation to the Berlin situation post-1990 lay in its potential to alleviate the city's water quantity and quality problems. As talk of a water supply crisis subsided in the mid-1990s, the emphasis of attention shifted firmly onto issues of water pollution. At this time the Berlin parliament set a target for raising the quality of Berlin's waterways to EU bathing water standards. One of the major obstacles to meeting this political commitment has been pollution from urban run-off. Currently between 80 and 100 mill. $\mathrm{m}^{3}$ of rainwater is collected annually in Berlin; around one third in mixed sewer systems, which is treated in STPs, the remaining two thirds being discharged largely untreated into the city's waterways (28). By the time the rainwater reaches the waterways it has often become contaminated with dust, waste, excrement, oil, rubber etc. collected from roofs, streets and drainpipes on its way through the system. Heavy rainfall has regularly led to serious overpollution of Berlin's waterways, especially after long dry periods.

This environmental pressure, backed up by the political objective to improve surface water quality, has caused both the water utility BWB and the environmental regulator SenSUT to cast aside initial reservations about the integration of a localized technology into a centrally structured system and to support the application of rainwater percolation in the city on a large scale. For SenSUT, the technology has become a key instrument to rainwater management, now regarded as the principal problem area of urban water management in Berlin (Interview 1). BWB has also, since the mid-1990s, been won over by the arguments in favor of the technology, attracted in addition by the possibility of avoiding investments in centralized rainwater retention/overflow basins and of down-scaling the dimensions of rainwater sewers in new and existing urban developments.

As a result, policies and programs have been devised to promote the localized percolation of urban run-off in Berlin. In 1992 the Senate approved a policy objective for the technology to applied wherever possible (2). Programs have been funded to encourage the desealing of sealed surfaces, such as paved courtyards, and the grassing of roofs. More important, though, was the agreement between the Senate and the BWB for a new concept of rainwater management which has been applied to all major planning developments since the mid-1990s. This specifies that urban run-off from residential areas, parking lots and streets with less than 2,000 vehicles a day should be percolated wherever possible on site (5) (Interview 3). Only run-off from polluted industrial sites and busy roads with over 2,000 vehicles per day should continue to be collected in rainwater sewers and treated before discharge. On the basis of this agreement, SenSUT and BWB consider storm-water percolation desirable for most current urban developments in Berlin.

Consequently, the extent of the application of the technology is far greater than in other German cities. Localized storm-water percolation is being introduced not as a demonstration project with special funding but as an element of the large-scale building program of a reunified Berlin (Interview 3). It has already been introduced extensively in major development areas in Karow-Nord, Rummelsburger Bucht and Adlershof (see Figure 3 and Table 1).

Figure 3: Map of Berlin indicating new development areas with extensive application of localized storm-water percolation 
Table 1: Extent of localized storm-water percolation in major development projects in Berlin

\section{Impacts of the new technology}

What impacts is the technology of storm-water percolation having on the existing system of waste water management? It is not within the scope of this paper to analyze the technical problems encountered in introducing a localized technology into a centrally structured sewer system. Here it is enough to point out that there is a limit to the scale of disconnection from a mixed sewer network, which relies on the occasional "flushing" effect caused by heavy rainfall. As yet, however, there have been no reports in Berlin of the existing sewer network failing to function properly owing to the decreased flow of waste water. The creation of localized sub-systems within Hobrecht's original structure has, according to the engineers responsible, had a generally beneficial effect, relieving the strain of excessive storm-water and permitting the down-scaling of rainwater sewers during refurbishment. Some technical questions do remain regarding the new technology, notably over its ability to function in frost and over possible soil contamination from continuous percolation. The principal systembuilders agree, however, that the principal obstacles to application are no longer technical, but social.

The introduction of storm-water percolation has brought to the surface not only water flows, in the shape of ponds and troughs, but also - in a figurative sense - the social relations which underpin waste water management. In terms of social structures and processes the extensive application of this localized technology marks a partial departure from conventional forms of water management. On-site rainwater management is no longer the realm of a sole utility and treated as a branch of sewage disposal. A far larger number of actors are now involved, ranging from the architects incorporating retention troughs in green spaces and the property owners installing and maintaining them to the borough parks departments mowing the grass of troughs in public spaces. Bringing technology above ground has thus altered the actor constellation in this sub-system of waste water management and re-ordered the roles of each actor group, shifting responsibility from the utility - traditionally responsible for underground infrastructure - onto other involved parties. This partial redistribution of tasks and responsibilities established and consolidated over a period of some one hundred years is revolutionizing the social organization of waste water management. It has required an ongoing process of re-negotiation between the relevant actor groups, analyzed in more detail below.

\section{Re-negotiation of responsibilities}

One of the primary fields of re-negotiation is over the use of space. The percolation of urban run-off places new demands on urban space which has created a conflict of interest between water managers on the one hand and urban planners and architects on the other. It has been estimated that for new urban developments a simple trough system for rainwater percolation requires an area of between 7 and $15 \%$ of the sealed surface area from which rainwater is collected (28). In Berlin's development projects this proportion has ranged between 7 and $10 \%$. This means taking up space on private property, at the side of small streets or on public green spaces which would otherwise be used for other functions. Many urban planners and architects resent the new technology for, as they see it, placing restrictions on their use of urban space. They object to having to "sacrifice" valuable urban space to make way for localized percolation systems or de-sealing measures, whether it be in a small private garden, a large urban green area or space otherwise earmarked for cycle paths and pavements (15). Behind the spatial argument lies an issue of aesthetics. Percolation troughs and ponds are 
criticized by architects in particular for being too "rural" and unsuited for new developments in a budding metropolis (7).

The water managers in BWB and SenSUT, along with other proponents of the new technology, dispute the view that their percolation systems are at the expense of other spatial functions, claiming that open water spaces can enhance urban design and landscaping. They criticize architects and urban planners, in turn, for a lack of fantasy in integrating percolation systems into their designs and point to a number of successful examples from earlier pilot projects (4) (Interview 3). What has emerged from past experiences in Berlin and elsewhere is that the claims to space posed by percolation systems require better integration and closer cooperation between land-use and infrastructure planning from an early stage in the planning process (4) (33) (Interview 3).

A second area requiring a re-negotiation of responsibilities is rainwater disposal. In the past the water/sewage utility, BWB, has been the sole operator of all technical systems for rainwater collection, treatment and disposal beyond the individual properties. Since all rainwater from sealed surfaces was simply collected in drainpipes and transported straight to a sewer or underground rainwater channel, the dividing line between the property - the responsibility of the developer or owner - and the sewer network - that of the BWB - was largely clear and undisputed. The advent of localized storm-water percolation has complicated this picture by introducing a technique which increases the responsibilities of property owners and developers for rainwater management, thus blurring the traditional distinction between service provider and user in this field. The owner not only has to pay for the installation of percolation systems on his property but has to maintain and repair them, ensuring for instance that percolation troughs continue to function in winter. In this way property owners and their tenants are, in effect, taking over part of the function of the water/sewage utility as rainwater managers.

How controversial this process of renegotiating roles can be is illustrated by the conflict of interest between BWB and borough parks departments over who should maintain troughtrench systems in public spaces. The BWB position is that it - as the sewage utility - is responsible solely for the underground sewer network, not for techniques above ground. Since the percolation troughs serving roads are surface installations, they should be maintained by the borough parks departments responsible for this public space. The parks departments themselves, not surprisingly, object to acquiring a new task for which they receive no additional funding and from which they derive no direct benefit. Whilst they argue against a redistribution of responsibilities and costs at a time of public sector cutbacks, BWB is drawing on historical precedent to illustrate how its past responsibility for rainwater management in total was shaped by the dominant technology of the day - the central sewer system. As one leading BWB representative put it: "In the past it was so convenient [for the boroughs] that the waste water was under the street - they didn't have to bother about it" (Interview 3). In the absence of a legal resolution to the conflict, BWB is currently engaged in separate negotiations with each of Berlin's 23 boroughs.

As responsibility for local rainwater management has shifted from utility to property owner, so too has liability for damage caused by malfunctioning rainwater collection systems. Whereas with a central sewer system a property owner can claim damages from the utility for such problems as damp arising from a leaking or blocked sewer, he himself is responsible for the functioning of rainwater percolation systems on his property and in principle liable for any damage caused to a neighbor's property. In practice, the extent of his liability is still a matter of legal dispute. The problem - as with the other areas of re-negotiation - rests on having to redraw the dividing line between utility and property owner to accommodate a technology which lies across previous, more clearly defined boundaries of social relations.

Finally, the new technology is raising questions about the distribution of costs for rainwater management. One of the main reasons for the large-scale application of storm-water 
percolation in Berlin's new urban developments is the considerable savings to be made over a conventional rainwater sewer system. It has been demonstrated elsewhere that, despite higher planning and design costs, a trough-trench system can save up to two thirds of investment costs (4). The savings apply in particular when - as in the case of Berlin - the conventional central solution would require the construction of rainwater retention and treatment plant to minimize surface water pollution. In the case of the Rummelsburger Bucht project, for example, some 9 mill. DM were saved against the estimate for a conventional solution. Such a favorable cost structure does not, of course, apply to retrofitting existing infrastructure, where the original outlay on the sewer network limits the savings that can be made.

The essential question remains, for both new developments and refurbishment, of how the costs are distributed and who benefits from the savings. One of the principal beneficiaries is the large-scale property developer who would otherwise have to pay for a rainwater sewer network linking all buildings on the property to the public sewer system and for the costs of connection. Since developers pay up to $90 \%$ of investment costs for technical infrastructure on their property, they can make considerable savings by avoiding unnecessary infrastructure investment. The recent Structural Plan for the districts of Kaulsdorf and Mahlsdorf, for instance, proposes the percolation of urban run-off specifically in order to avoid the construction of a rainwater sewer (15). The Berlin Senate is a second beneficiary in that it would otherwise have to pay $100 \%$ of the costs for rainwater retention basins and $60 \%$ of the costs for storm-water overflow basins in a mixed sewage system. The more urban run-off is percolated locally, the less need there is to build these costly retention and overflow basins - a clear financial advantage for the Senate. Finally, BWB benefits from avoiding the remaining $40 \%$ of investment costs on mixed sewer overflow basins and, as we have seen, from reduced responsibilities for on-site rainwater management.

A major disincentive for the owner-occupier against introducing storm-water percolation lies in the pricing system for water and sewage services. Currently, there is no saving on water rates to be made by percolating rainwater on site. Consumers pay a sewage rate of 4.85 DM per $\mathrm{m}^{3}$ which is calculated according to the amount of drinking water used. In order to encourage local percolation of urban run-off the Senate has decided to split the water rate in Berlin, reducing the sewage charge by $1.00 \mathrm{DM}$ per $\mathrm{m}^{3}$ and introducing a new charge on the collection and treatment of rainwater based on the sealed surface area of a property. This initiative is presented as a more just distribution of the costs for rainwater disposal services, which amount to some $20 \%$ of all waste water disposal costs in Berlin. In future, those with a low level of sealed surfaces, permitting rainwater percolation on site, will pay a low rainwater charge, whilst those with extensive sealed ground will pay a high rainwater charge.

The new water pricing system is not free of controversy, however. The Berlin Chamber of Commerce (IHK) has voiced its opposition to a scheme which would, overall, create an additional financial burden on business and increase administrative costs, not least on surveying $900 \mathrm{~km}^{2}$ to establish the proportion of sealed surface for every single property in the city. It also raises a social question regarding the distribution of costs between different types of housing. Whilst tenants in high-rise blocks will benefit from a favorable user-tosealed-area ratio and owner-occupiers in suburban areas from their ability to de-seal surfaces, the new scheme based on the "polluter pays" principle will hit residents of inner-city areas where de-sealing and storm-water percolation are often not viable. The promotion of a new technology has thus opened up a "black-box" of complex issues of social justice, cost distribution and urban governance relevant to rainwater management which will need to be established on a fresh footing if the technology is to succeed. 


\section{Conclusion}

Experiences in Berlin with the application of various techniques for percolating urban run-off locally offer interesting lessons on the interaction between technical and social components of a Large Technological System. This paper has demonstrated, on the one hand, how the development trajectory of an infrastructure system for collecting, treating and disposing of waste water is shaped by multiple forces not only of a technical, physical or environmental nature, but also social, organizational and political. The interplay of these forces and the way they have been interpreted by generations of system-builders have provided the direction and momentum for the consolidation and expansion of high-performance technical networks over the past century. Viewed in such broad terms, the development of Berlin's waste water disposal system follows largely the theoretical model of the Large Technological System (LTS) concept.

However, a closer look at one transitional phase in the history of Berlin's sewage system - the period since re-unification in 1990 - reveals that the process of transformation is inadequately explained by the conflictual LTS notion of a "battle of systems" between competing systems resulting in one replacing the other. Firstly, there was not one but a number of diverse reverse salients challenging the established logics of sewage management. Partly as a result of this there was, secondly, no clear-cut choice between two alternatives; the issue was rather about which technical solutions proved most suited to the new circumstances, permitting in this case the coexistence of localized storm-water percolation within a centralized sewer system. Thirdly, the circumstances themselves were constantly shifting (e.g. the sharp, unpredictable decline in water consumption), thus laying great importance on the adaptability of technologies to different contextual conditions. Taking these observations into account, the process of technological innovation in the case study can be characterized as one of exploiting "openings" created - sometimes only briefly - by a particular constellation of local contextual factors.

The second important lesson to be drawn from the paper is how technical systems themselves shape the social context of their management. The recent introduction of stormwater percolation in Berlin has transformed the social organization and relations underpinning rainwater management in those sections of the network. The task of rainwater disposal there is no longer the responsibility of the local water utility alone but of a wide range of actors previously uninvolved in water management, such as property owners and developers, architects, town planners and parks departments. As the traditional divide between service provider (the utility) and service user (all others) is gradually eroded and a new consensus is sought, each actor group has been trying to derive maximum benefit from the redistribution of responsibilities. Over such controversial issues as the use of urban space, sewage disposal, the distribution of costs and liability a negotiation process is still underway to map out fresh boundaries of responsibility between the relevant parties, thus re-framing the social organization of an important sub-system of urban water management.

Note: An earlier version of this paper was presented at the conference "Sustainability, Risk and Nature: the political ecology of water in advanced societies" organized by the Department of Geography at the University of Oxford, 15-17 April 1999. 


\section{Bilbliography}

1. Abgeordnetenhaus von Berlin, Gemeinsames Landesentwicklungsprogramm der Länder Berlin und Brandenburg 13. Wahlperiode. Drucksache 13/1885 (Berlin: Abgeordnetenhaus von Berlin, 1997).

2. Abgeordnetenhaus von Berlin, Integriertes und umweltgerechtes wasserwirtschaftliches Konzept für den Großraum Berlin 12. Wahlperiode. Drucksache 12/4849 (Berlin: Abgeordnetenhaus von Berlin, 1992).

3. Berliner Wasser Betriebe, Geschäftsbericht 1996 (Berlin: BWB, 1997).

4. Bundesministerium für Raumordnung, Bauwesen und Städtebau, ed., Regenwasserversickerung in Siedlungsgebieten (Bonn-Bad Godesberg: BMBau, 1997).

5. M. Böhme, "Regenwassernutzung in Berlin," in Umweltbundesamt, ed., Regenwassernutzung im Haushalt (Berlin: Umweltbundesamt, 1995).

6. Bund für Umwelt und Naturschutz Deutschland, Konzeption einer ressourcenschonenden Wasserbewirtschaftung für die Region Berlin. Kurzfassung (Berlin: BUND, 1993).

7. K. Bundschuh, "Die Ästetisierung des Banalen. Regenwassertechnologie contra Gartenkunst," Stadtforum 25 (May 1997).

8. W. Dorau, "Mit technischen Maßnahmen der Wasseraufbereitung den ökologischen Wasserkreislauf im Kleinen nachahmen," in Senatsverwaltung für Stadtentwicklung und Umweltschutz, ed., Umwelt- und Naturschutz für Berliner Gewässer (Berlin: SenStadtUm, 1990).

9. R.J. Evans, Death in Hamburg. Society and Politics in the Cholera Years 1830-1910 (Harmondsworth: Penguin, 1990).

10. L. Galambos, "A View from Economic History," in T.R. La Porte, ed., Social Responses to Large Technical Systems. Control or Anticipation (Dordrecht: Kluwer Academic Publishers, 1991).

11. I. Gökalp, "On the Analysis of Large Technical Systems," Science, Technology and Human Values 171 (1992).

12. S. Guy, S. Graham and S. Marvin, "Splintering Networks: Cities and Technical Networks in 1990s Britain," Urban Studies 342 (1997).

13. S. Guy and S. Marvin, "Disconnected Policy, the shaping of local energy management," Environment and Planning (C): Government and Policy 141 (1996).

14. C. Hildmann and W. Ripl, "Sustainable Berlin by Process Coupling between City and Catchment," in J. Breuste, H. Feldmann and O. Uhlmann, eds., Urban Ecology (Berlin/Heidelberg: Springer, 1998).

15. H.W. Hoffmann, "Der große Schwamm. Nachhaltiges Wassermanagement als Bestandteil der Stadtentwicklungsplanung," Stadtforum (November 1997).

16. T. Hughes, "The Evolution of Large Technological Systems," in W.E. Bijker, T.P. Hughes and T. Pinch, eds., The Social Construction of Technological Systems (Cambridge: MIT Press, 1987).

17. T. Hughes, Networks of Power: Electrification in Western Society 1880-1930 (Baltimore, John Hopkins University Press, 1983).

18. D. Jahn, "Wasserwirtschaftliche Grundlagen der Regenwassernutzung in Berlin," in Umweltbundesamt, ed., Regenwassernutzung im Haushalt (Berlin: Umweltbundesamt, 1995).

19. F. Langbein, "Der Werdegang der Berliner Stadtentwässerung," in H. Hahn and F. Langbein, eds., Fünfzig Jahre Berliner Stadtentwässerung 1978-1928 (Berlin: Alfred Metzner Verlag, 1928).

20. S. Marvin and S. Guy, "Infrastructure Provision, Development Processes and the Coproduction of Environmental Value," Urban Studies 3412 (1997). 
21. T. Moss, "Battle of the Systems? Changing Styles of Water Recycling in Berlin", in T. Moss, S. Marvin and S. Guy, eds., Urban Infrastructure in Transition: Networks, Buildings, Plans (in preparation).

22. E. Nolde, "Wassernöte in Ballungsgebieten?" Politische Ökologie Sonderheft 5 (1994).

23. J. Oßenbrügge, Umweltrisiko und Raumentwicklung. Wahrnehmung von Umweltgefahren und ihre Wirkung auf den regionalen Strukturwandel in Norddeutschland (Berlin/Heidelberg: Springer, 1993).

24. W. Ripl and C. Hildmann, "Zwei in einem Boot," Politische Ökologie 44 (1996).

25. P. Schirmer, "Wasserwirtschaftliche Erfahrungen und Bedeutung für UmweltPartnerstädte," in Senatsverwaltung für Stadtentwicklung und Umweltschutz, ed., Umsetzung der Klimarahmenkonvention und Emissionsminderung in Ballungsräumen (Berlin: SenSUT, 1995).

26. E. Schramm, "Das Kreislaufmodell im städtischen Wasserhaushalt," WasserKultur 3 (1994).

27. D. Schulze, "Wassermengenwirtschaft im Ballungsraum Berlin. Probleme und Lösungsansätze," Lecture at seminar Wasserkrise in der Region Berlin/Brandenburg? (April 1997).

28. Senatsverwaltung für Stadtentwicklung, Umweltschutz und Technologie, ed., Stadtentwicklungsplan Ver- und Entsorgung. Grundlagen (Berlin: Regioverlag, 1998).

29. C.J. Soeder, "Perspektiven der kommunalen Abwasserreinigung für die Wasserversorgung urbaner Ballungsräume," Wasserwirtschaft 86 (1996).

30. J. Summerton, "Introductory Essay: The Systems Approach to Technological Change," in J. Summerton, ed., Changing Large Technical Systems (Colorado: Westview Press, 1994).

31. H. Tessendorf, "Siedlungswasserwirtschaft für Berlin und das Umland," Wasser + Boden 4 (1993).

32. Umweltbundesamt, ed., Regenwassernutzung im Haushalt (Berlin: Umweltbundesamt, 1995).

33. H. Wassmann, Grundlagen einer immissionsorientierten Regenwasserbewirtschaftung in Ballungsräumen - dargestellt am Beispiel des Landes Berlin (Berlin: Umweltbundesamt, 1996).

\section{Interviews}

Interview 1: Representative of the Senate Department for Urban Development, Environmental Protection and Technology (SenSUT), Water Authority - General Planning Dept., 1 August 1997.

Interview 2: Representative of the Berlin water utility (BWB), Corporate Planning Dept., 6 August 1997.

Interview 3: Representative of the Berlin water utility (BWB), Network Construction Dept., 28 October 1997. 